\title{
The role of surgery in primary central nervous system lymphomas
}

\author{
El rol de la cirugía en los linfomas primarios del sistema nervioso central \\ Juan Francisco Villalonga ${ }^{1}$, Lucas Alessandro', Mauricio Franco Farez ${ }^{2,3}$, Rubén Mormandi', Andrés Cervio ${ }^{4}$, \\ Santiago Condomi Alcorta ${ }^{1}$, Alejandro Muggeri ${ }^{1}$
}

\begin{abstract}
Background: Primary central nervous system lymphomas (PCNSL) are infrequent. The traditional treatment of choice is chemotherapy. Complete resections have generally not been recommended, because of the risk of permanent central nervous system deficits with no proven improvement in survival. The aim of the current study was to compare survival among patients with PCNSL who underwent biopsy versus surgical resection. Methods: A retrospective study was conducted on 50 patients with a confirmed diagnosis of PCNSL treated at our center from January 1994 to July 2015. Results: Patients in the resection group exhibited significantly longer median survival time, relative to the biopsy group, surviving a median 31 months versus 14.5 months; $p=0.016$. Conclusions: In our series, patients who had surgical resection of their tumor survived a median 16.5 months longer than patients who underwent biopsy alone.
\end{abstract}

Keywords: lymphoma; therapeutics; biopsy; survival.

\section{RESUMO}

Introducción: Los linfomas primarios del sistema nervioso central (LPSNC) son infrecuentes. Tradicionalmente el tratamiento de elección es la quimioterapia. Existe un paradigma de no indicar resección, por el riesgo de déficit neurológico sin aumento de la sobrevida. El objetivo del presente estudio es comparar la sobrevida de pacientes con LPSNC sometidos a biopsia versus resección. Métodos: Estudio retrospectivo que incluye 50 pacientes con diagnóstico confirmado de LPSNC tratados en nuestra Institución desde enero de 1994 hasta julio de 2015. Resultados: Los pacientes del "grupo resección" mostraron una sobrevida media significativamente mayor respecto a los del "grupo biopsia"; 31 meses versus 14,5 meses respectivamente, $p=0,016$. Conclusiones: En nuestra serie, los pacientes que con resección quirúrgica de su tumor tuvieron una sobrevida media de 16,5 meses superior que los pacientes biopsiados.

Palabras-clave: linfoma; terapéutica; biopsia; sobrevivencia.

Primary central nervous system lymphomas (PCNSL) are an infrequent variant of extranodal, non-Hodgkin's lymphoma that involves different structures within the central nervous system (CNS), in the absence of systemic involvement. The entity was first described by Bailey in $1929^{1}$ and, from 1974 onward, has been recognized as a distinct nosological entity ${ }^{2}$. Its incidence is 0.47 cases per 100,000 persons annually ${ }^{3}$. These tumors represent $3 \%$ of all intracranial neoplasms, $1 \%$ of all lymphomas, and 4-6\% of all extranodal lymphomas ${ }^{4}$. The most important risk factor is immunodepres$\operatorname{sion}^{5}$. Over the past three decades, the incidence of PCNSL has increased in immunocompetent patients of advanced age $^{3}$, though currently its incidence has plateaued and appears to be descending in those who are immunocompromised, especially among those who are human immunodeficiency virus (HIV) positive, with or without AIDS, since the emergence of so-called highly-active antiretroviral therapy ${ }^{6}$. The cancer's highly pleomorphic presentation, both clinically and on imaging, can render recognition of this entity difficult, such that it is often mistaken for infectious illness, auto-immune disease, and even other tumors affecting the $\mathrm{CNS}^{7}$. Prognostic factors associated with decreased survival are age over 60 years, Eastern Cooperative Oncology Group (ECOG) functional status over 1 (indicating at least significant time spent in bed during an average day), elevated serum levels of lactate dehydrogenase, increased proteins

\footnotetext{
${ }^{1}$ Fundación para la Lucha contas las Enfermedades Neurologicas de la Infancia, Departmento de Neurocirurgía, Buenos Aires, Argentina;

${ }^{2}$ Center for Research on Neuroimmunological Diseases (CIEN), Buenos Aires, Argentina;

${ }^{3}$ Raúl Carrea Institute for Neurological Research (FLENI), Buenos Aires, Argentina;

${ }^{4}$ Raúl Carrea Institute for Neurological Research (FLENI), Departamento de Neurocirurgía, Buenos Aires, Argentina.
}

Correspondence: Juan Francisco Villalonga; Fundacion para la Lucha contra las Enfermedades Neurologicas de la Infancia, Departamento de Neurocirugía; Montañeses 2325 Ciudada Autonoma de Buenos Aires Buenos Aires C1428QK, Argentina; E-mail: jfvillalonga@hotmail.com

Conflict of interest: There is no conflict of interest to declare.

Received 26 September 2017; Received in final form 05 December 2017; Accepted 09 December 2017. 
in cerebrospinal fluid (CSF), and involvement of deep cerebral regions ${ }^{8}$. Polychemotherapy that includes high doses of methotrexate is the standard treatment, producing variable response rates that range from $35 \%$ to $96 \%$.

Median survival is 17-45 months in immunocompetent individuals, and 13.5 months in those who are immunocompromised $^{10}$. The lymphoma is considered to be an infiltrating tumor often associated with diffuse, multicentric lesions, despite contrary evidence on imaging (when matched to autopsy findings $)^{11}$. This is why surgical resection has largely been felt to play a minor role and to impact survival only minimally. For this reason, it has traditionally been recommended that any surgical intervention should be limited to obtaining biopsy tissue, thereby contributing to the diagnosis but not to the treatment of this cancer ${ }^{12,13,14}$. On the other hand, some retrospective data suggest that cytoreduction, when possible, can improve survival ${ }^{15}$. It is difficult to evaluate the real impact of this practice, however, in nonrandomized, uncontrolled retrospective studies, due to the potential for significant selection bias.

The aim of the current study was, therefore, to retrospectively compare survival in patients with PCNSL who undergo biopsy alone versus those who have surgical resection.

\section{METHODS}

For this analysis, we performed a retrospective review of the case histories of 50 patients with PCNSL treated at our institution between January 1994 and July 2015 and followed for a median of 31 months (range: 12-245 months). The following data were collected and recorded: patient demographics; past medical history; HIV serology; clinical presentation; abnormal physicochemical analysis; CSF analysis (including cytology and cytometrics); slit-lamp fundoscopic examination of the eyes; magnetic resonance imaging of the brain and spinal column; details of the surgical procedure; tumor histology; short-term postoperative course; and course over long-term follow-up.

Diagnosis was confirmed by means of tissue analysis assessing both gross anatomy and histopathology. Biopsy sample was obtained by means of surgical resection $(n=18)$, stereotactic biopsy $(n=21)$, open biopsy $(n=7)$ and endoscopic biopsy $(n=1)$. In two patients, the diagnosis was made by means of flow cytometry of CSF, and in one via cytological examination of the vitreous body.

Included in the study were patients who presented with lymphoma limited to the CNS at the time of diagnosis. Systemic involvement was ruled out by means of the following a) CT scan of the neck, thorax, abdomen and pelvis with double contrast, or total body PET scan with fluorodeoxyglucose; and b) bone marrow aspiration in patients suspected of systemic involvement. The type of surgery and the extent of resection were recorded according to surgical protocols and interpretation of the postoperative magnetic resonance imaging. The patient's global functional state at the time of diagnosis and throughout follow-up was evaluated using the scale developed by the ECOG to measure functional status specifically in cancer patients ${ }^{16}$.

For statistical analysis, patients were divided into two groups: 1) biopsy alone (whether stereotactic, open, or endoscopic) and 2) resection (whether total or partial). For analysis, we used the statistical computer software Stata, Version 12. Categorical variables were described in terms of both frequencies and percentages, while continuous variables were described in terms of their mean, median, centiles, and minimum-to-maximum range. Kaplan-Meier estimation function graphs were then constructed to analyze the relationship between different predictors and the time-to-death variable individually, and any associations evaluated through log-rank tests.

\section{RESULTS}

The median age of patients at the time of presentation was 59 years (range: $25-4$ years). Two-thirds of the patients $(66 \%)$ were men $($ male/female ratio $=1.94: 1)($ Table 1$)$. Eighty-four percent of the patients were considered immunocompetent at the time of diagnosis, while the remaining $16 \%$ presented with some level of immunocompromise. Causes of immunocompromise included autoimmune disease requiring immunosuppressive treatment (one patient each with rheumatoid arthritis, myasthenia gravis, and Erdheim-Chester syndrome); previously-diagnosed cancer treated with chemotherapy $(\mathrm{n}=2)$; organ transplantation on immunosuppressive treatment $(\mathrm{n}=1)$; and HIV ( $\mathrm{n}=2$ ). Type B non-Hodgkin's lymphomas were the most frequent form (96\%). There was only a single case each of a T-cell lymphoma and natural killer cell lymphoma. Pyramidal syndrome was the most frequent initial presentation (55\%). Other notable presentations were rapid cognitive deterioration (36\%) and intracranial hypertension (8.5\%) (Table 1). In 18 patients, CSF analysis was considered confirmatory, with physicochemical analysis abnormal in $66 \%$, but only $12 \%$ demonstrating lymphoma cells.

Among patients operated on, a parenchymal pattern was predominant $(87 \%)$. The most commonly-affected lobe was the frontal, at $45 \%$, and $23 \%$ had basal ganglia involvement. Twenty-three percent of the tumors were multicentric and $8.5 \%$ exhibited decussation across the midline (Table 1). Forty-seven of the fifty patients (94\%) underwent surgical intervention (Figure 1): 29 patients had biopsy alone (58\%) and 18 patients had surgical resection (36\%).

In 42 patients (84\%), adequate follow-up was achieved, which included both clinical and radiological assessments. The median duration of follow-up was 31 months (range: 12-245 months). Forty-six patients (92\%) received chemotherapy, which included high-dose methotrexate. Median survival was 25 months (range: 2-218 months). Twenty-two of the patients (41\%) were still alive after 245 months of follow-up. 
Table 1. Comparing patients who underwent biopsy alone versus surgical resection.

\begin{tabular}{|c|c|c|c|c|}
\hline Variables & Total $n=47$ & Biopsy $n=29$ & Resection $n=18$ & $\mathrm{p}$-value \\
\hline \multicolumn{5}{|c|}{ Demographics } \\
\hline Age of presentation; mean (range) & $60(25-84)$ & $61(27-81)$ & $59(25-84)$ & 0.73 \\
\hline Men;n (\%) & $30(64 \%)$ & $16(55 \%)$ & $14(78 \%)$ & 0.13 \\
\hline \multicolumn{5}{|c|}{ Immunological status } \\
\hline Immunodeficient; n (\%) & $8(17 \%)$ & $5(17 \%)$ & $3(17 \%)$ & 0.96 \\
\hline \multicolumn{5}{|c|}{ Type of lymphoma } \\
\hline Type B & $45(96 \%)$ & $28(96.5 \%)$ & $17(94 \%)$ & \\
\hline Type T & $1(2 \%)$ & $0(0 \%)$ & $1(5.5 \%)$ & 0.62 \\
\hline Type NK (natural killer) & $1(2 \%)$ & $1(3.4 \%)$ & $0(0 \%)$ & \\
\hline \multicolumn{5}{|c|}{ Manifestations; n (\%) } \\
\hline Pyramidal & $26(55 \%)$ & $17(58.6 \%)$ & $9(50 \%)$ & 0.56 \\
\hline Cognitive disorders & $17(36 \%)$ & $7(24 \%)$ & $10(55.5 \%)$ & 0.03 \\
\hline Intracranial hypertension & $4(8.5 \%)$ & $1(3.4 \%)$ & $3(17 \%)$ & 0.15 \\
\hline \multicolumn{5}{|c|}{ Engaged areas on MRI } \\
\hline Frontal lobe & $21(45 \%)$ & $12(41.4 \%)$ & $9(50 \%)$ & 0.56 \\
\hline Basal ganglia & $11(23 \%)$ & $10(34.5 \%)$ & $1(5.5 \%)$ & 0.033 \\
\hline Decussation through midline & $4(8.5 \%)$ & $3(10.3 \%)$ & $1(5.5 \%)$ & 0.99 \\
\hline Multicentric & $11(23 \%)$ & $7(24.3 \%)$ & $4(22 \%)$ & 0.99 \\
\hline \multicolumn{5}{|c|}{ Pattern;n(\%) } \\
\hline Parenchyma & $41(87 \%)$ & $26(90 \%)$ & $15(83 \%)$ & \\
\hline Meningeal & $3(6.5 \%)$ & $2(7 \%)$ & $1(5.5 \%)$ & 0.8 \\
\hline Mixed & $3(6.5 \%)$ & $1(3.4 \%)$ & $2(11 \%)$ & \\
\hline
\end{tabular}

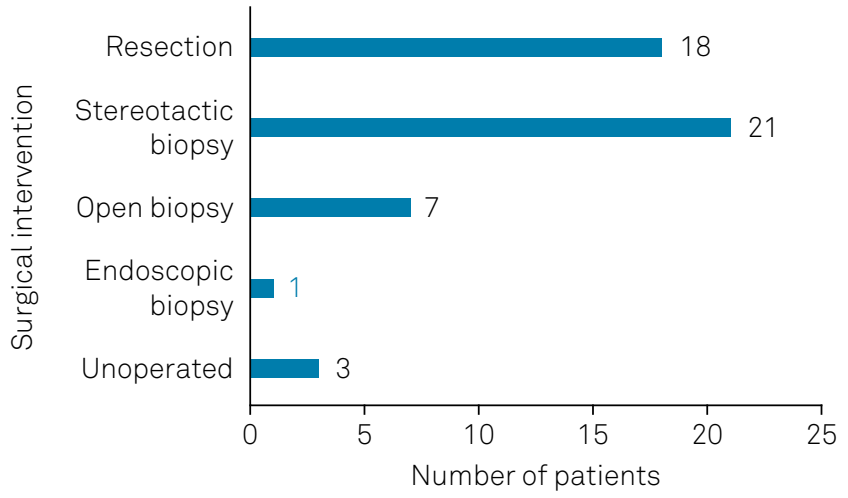

Figure 1. Distribution of patients by treatment arm: biopsy versus surgical resection.

There were no significant differences between patients in the biopsy and resection groups for any of the following variables: a) baseline ECOG ( $p=0.21$; Table 2); b) immune status ( $p=0.96$; Table 1); or c) prescribed chemotherapy. One statistically significant difference $(\mathrm{p}=0.033)$ was a greater percentage of biopsy patients with a deep location of tumor, involving basal ganglia (Table 1).

In terms of outcome, survival time was much longer among patients in the resection group, with a median survival of 31 months (range: 4 -194) versus 14.5 months (range: $2-77)$ in the biopsy alone group $(\mathrm{p}=0.016)$ (Table 2; Figure 2). When only immunocompetent patients were considered, this survival difference lost its significance $(\mathrm{p}=0.07)$ (Figure 3), though a trend towards prolonged survival in surgery patients remained apparent. On the other hand,
Table 2. Outcomes by treatment arm: biopsy versus surgical resection.

\begin{tabular}{lcccc} 
Variables & $\begin{array}{c}\text { Total } \\
\mathrm{n}=47\end{array}$ & $\begin{array}{c}\text { Biopsy } \\
\mathrm{n}=29\end{array}$ & $\begin{array}{c}\text { Resection } \\
\mathrm{n}=18\end{array}$ & $\mathrm{p}$-value \\
\hline $\begin{array}{l}\text { Survival; median and } \\
\text { range (months) }\end{array}$ & $\begin{array}{c}25 \\
(2-218)\end{array}$ & $\begin{array}{c}14.5 \\
(2-77)\end{array}$ & $\begin{array}{c}31 \\
(4-194)\end{array}$ & 0.016 \\
$\begin{array}{l}\text { Preoperative ECOG; } \\
\text { mean }\end{array}$ & 1.4 & 1.55 & 1.16 & 0.21 \\
$\begin{array}{l}\text { Postoperative ECOG; } \\
\text { mean }\end{array}$ & 3.71 & 4.2 & 3.4 & 0.22 \\
$\begin{array}{l}\text { Deceased, } \mathrm{n}(\%) \\
(53 \%)\end{array}$ & $\begin{array}{c}15 \\
(52 \%)\end{array}$ & $\begin{array}{c}10 \\
(55.5 \%)\end{array}$ & 0.8 \\
\hline
\end{tabular}

ECOG: Eastern Cooperative Oncology Group functional status.

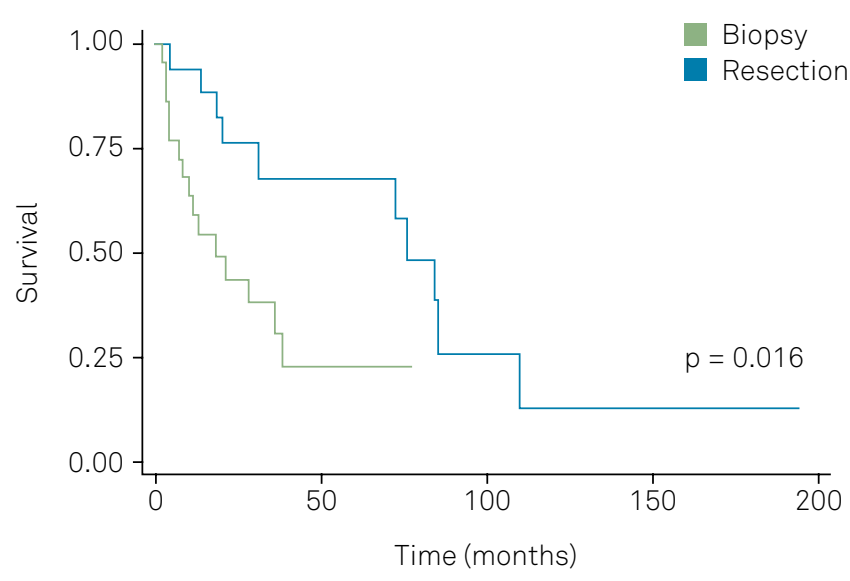

Figure 2. Survival by type of surgical intervention, irrespective of immunological status. 
comparing survival in immunocompetent versus immunocompromised patients revealed no difference, with median survival times of 24 months (range: 2-38) and 26 months (range: $3-218)$, respectively ( $p=0.2$ ) (Figure 4).

\section{DISCUSSION}

The current series of patients, in many ways, mimics descriptions of PCNSL patients in numerous prior reports, in terms of their demographics ${ }^{14,17}$, clinical, imaging and immunological status ${ }^{18}$ and histopathological findings ${ }^{19,20}$. As in these other series, most of our patients were men, of advanced age, immunocompetent, who had a type B lymphoma (Table 1). Consistent with the literature, considerable variability was observed in the patients' baseline clini$\mathrm{cal}^{21}$ and imaging findings $\mathrm{s}^{22,23}$. Cytological analysis of CSF is a non-invasive test that sometimes leads to the diagnosis, as happened in two of our patients. Nevertheless, as noted previously in the literature ${ }^{24}$, the sensitivity of CSF analysis in

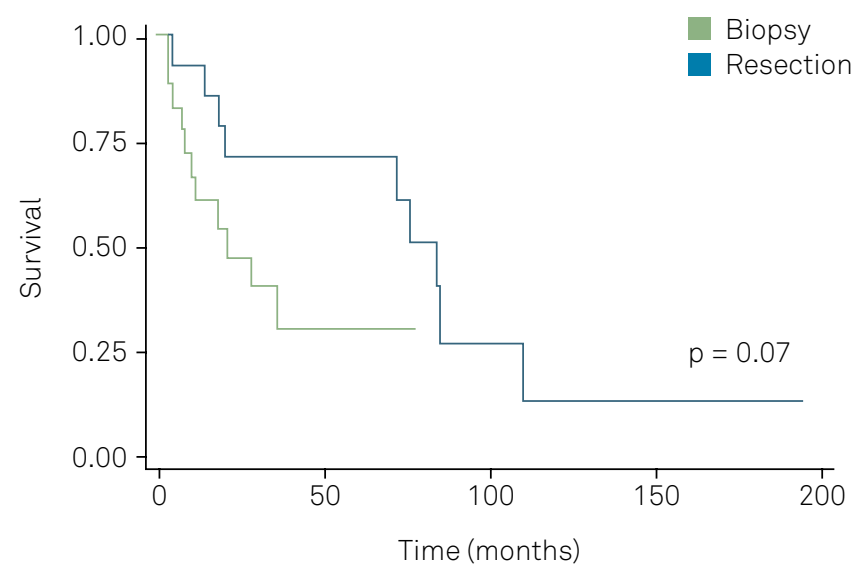

Figure 3. Survival by type of surgical intervention in immunocompetent patients.

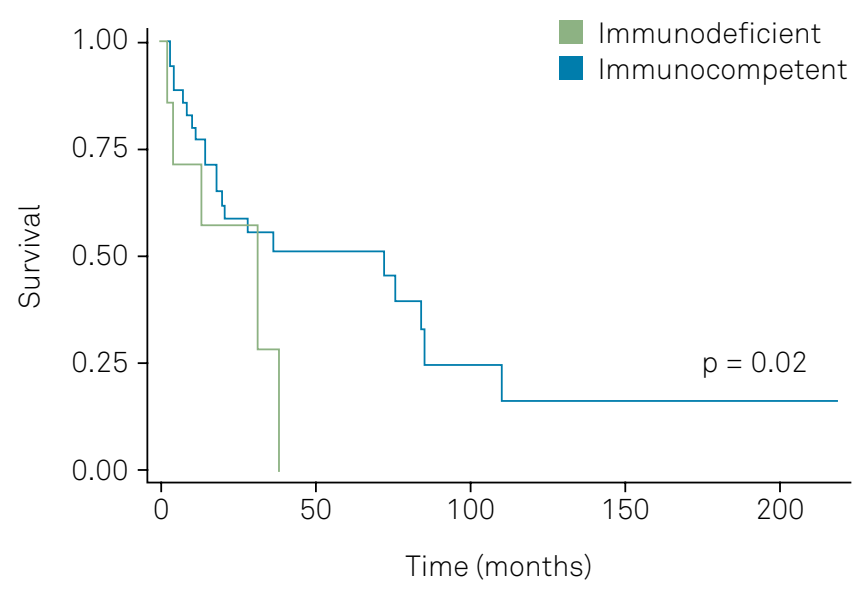

Figure 4. Overall survival in immunocompetent versus immunocompromised patients. our series was low (12\%). Another consideration is that some of these patients cannot tolerate lumbar puncture due to risk of brain herniation caused by intracranial hypertension. For all these reasons, the definitive diagnosis of this disease depends, to a great extent, on histopathological analysis. It is for this reason that neurosurgical intervention is fundamental to obtaining a representative sample that allows clinicians to arrive at a correct diagnosis. At our institution, we ensure adequate sampling by performing intra-operative neuropathological analysis to increase diagnostic efficacy.

To date, most published review articles and guidelines recommend that any neurosurgical intervention be limited to biopsy alone, avoiding resection. Those who advise against PCNSL resection have typically based their decision on: 1) the scarce evidence that surgical cytoreduction enhances survival relative to biopsy with subsequent chemotherapy ${ }^{25}$; and 2) the risk that postoperative sequelae will outweigh the benefits of surgery ${ }^{21,25}$. These concerns arise from retrospective analyses of older series with small numbers of patients ${ }^{12,13,14}$. In a study by Henry et al. in $1974^{2}$, for example, patients who were treated only with supportive measures $(n=15)$ survived an average of 3.3 months, with resection as the sole treatment $(n=28) 4.6$ months, and with radiotherapy (with or without surgical excision) ( $\mathrm{n}=21) 15.2$ months. De Angelis et al. observed in their series of 29 patients, that four of their 10 patients who underwent total resection developed severe neurological deficits, whereas no complications were observed in 19 patients in whom stereotactic biopsy was the sole surgical intervention ${ }^{26}$. Bataille et al. reported their retrospective study of 248 patients treated between 1980 and 1995, among whom one-year survival rates were similar in patients who underwent total resection (56.6\%), partial resection (31.8\%), and biopsy without resection (48.6\%); the authors also suggested that stereotactic biopsy was less risky than resection ${ }^{21}$. Similarly, Bellinzona et al. ${ }^{27}$ failed to demonstrate any benefit of surgery in their series of 33 PCNSL patients, and concluded that resection could be attempted in selected subgroups of patients, like those with bulky lesions and neurological deficits.

The first study to demonstrate any survival benefit of surgery in patients with PCNSL was published by Weller et al. in $2012^{25}$, who performed a secondary analysis of the database generated by the German PCNSL Group in $2010^{28}$. This study incorporated 551 patients with PCNSL drawn from 75 different centers, all evaluated between 2000 and 2009. The investigators found that patients who underwent surgical resection, whether partial or total, had longer recurrence/progression-free $(p=0.005)$ and global $(p=0.024)$ survival than biopsy-alone patients. However, most recent European guidelines fail to establish any consensus with regards to appropriate surgical practice in patients with a single resectable lesion, other than recommending resection of lesions that cause intracranial hypertension, and stereotactic biopsy of those that are nonresectable ${ }^{15}$. 
In the present study, the relative proportions of patients in the biopsy (58\%) and resection (36\%) groups are comparable to those reported for the series by Bataille et al. $^{21}$ and the German PCNSL Group in $2010^{28}$. Patients in the resection group experienced significantly increased survival time relative to those who underwent biopsy alone; in fact, surviving more than twice as long and adding a median 16.5 months to their life (median 31 versus 14.5 months, respectively). However, when only comparing immunocompetent patients in the two groups, statistical significance was lost, though a trend towards increased survival remained $(p=0.07)$.

Given the retrospective nature of our study, such that there was no random allocation of patients to the two treatment arms, one possible bias that must be considered when interpreting our results is that the patients in the biopsy group might have had more advanced baseline disease and, therefore, a worse baseline prognosis. However, we did not identify any significant intergroup differences in our initial cancer-specific evaluation of functional status (as measured using the ECOG scale) or in the percentage of patients with multicentric lesions, though biopsy patients were more likely to have deep lesions involving basal ganglia. We also noted no significant differences between the two patient groups in immunological status or the chemotherapy administered. On the other hand, when survival was assessed only considering baseline immunological status without considering the type of resection, survival was not significantly different in immunocompromised and immunocompetent patients.

In conclusion, since both the clinical and imaging presentation of PCNSL is very pleomorphic, some neurosurgical intervention is almost always necessary to make an accurate diagnosis, if for no other reason than to obtain biopsy tissue for analysis. However, in this study we identified not only significantly, but markedly-increased survival in our patients who underwent surgical resection relative to those who had biopsy alone, a survival difference of almost one-and-a-half years. This certainly warrants closer investigation, preferentially through a prospective randomized phase III study. In the meantime, we feel that resection should be considered at least in those patients who have single lesions that appear resectable at relatively low risk.

\section{References}

1. Bailey P. Intracranial sarcomatous tumors of leptomeningeal origin. Arch Surg. 1929;18(4):1359-402. https://doi.org/10.1001/archsurg.1929.01140130449031.

2. Henry JM, Heffner RR Jr, Dillard SH, Earle KM, Davis RL. Primary malignant lymphomas of the central nervous system. Cancer. 1974 Oct;34(4):1293-302. https://doi.org/10.1002/10970142(197410)34:4<1293::AID-CNCR2820340441>3.0.CO;2-P

3. Villano JL, Koshy M, Shaikh H, Dolecek TA, McCarthy BJ. Age, gender, and racial differences in incidence and survival in primary CNS lymphoma. Br J Cancer. 2011 Oct;105(9):1414-8. https://doi.org/10.1038/bjc.2011.357

4. Kluin PM, Deckert M, Ferry JA. Primary diffuse large B-cell lymphoma of the CNS. In: Swerdlow SH, editor. World Health Organization classification of tumours pathology and genetics of tumours of the haematopoietic and lymphoid tissues. Lyon: IARC Press; 2008. p. 240-4.

5. Schabet M. Epidemiology of primary CNS lymphoma.J Neurooncol. 1999 Jul;43(3):199-201. https://doi.org/10.1023/A:1006290032052

6. Kadan-Lottick NS, Skluzacek MC, Gurney JG. Decreasing incidence rates of primary central nervous system lymphoma. Cancer. 2002 Jul;95(1):193-202. https://doi.org/10.1002/cncr.10643

7. Hunt MA, Jahnke K, Murillo TP, Neuwelt EA. Distinguishing primary central nervous system lymphoma from other central nervous system diseases: a neurosurgical perspective on diagnostic dilemmas and approaches. Neurosurg Focus. 2006 Nov;21(5):E3. https://doi.org/10.3171/foc.2006.21.5.4

8. Fraser E, Gruenberg K, Rubenstein JL. New approaches in primary central nervous system lymphoma. Chin Clin Oncol. 2015 Mar;4(1):11. https://doi.org/10.3978/j.issn.2304-3865.2015.02.01

9. Okita Y, Narita Y, Miyakita Y, Miyahara R, Ohno M, Takahashi M et al. Health-related quality of life in outpatients with primary central nervous system lymphoma after radiotherapy and high-dose methotrexate chemotherapy. Mol Clin Oncol. 2016 Sep;5(3):179-85. https://doi.org/10.3892/mco.2016.962

10. Chamberlain MC. Long survival in patients with acquired immune deficiency syndrome-related primary central nervous system lymphoma.
Cancer. 1994 Mar;73(6):1728-30. https://doi.org/10.1002/10970142(19940315)73:6<1728::AID-CNCR2820730629>3.0.CO;2-8

11. Lai R, Rosenblum MK, DeAngelis LM. Primary CNS lymphoma: a whole-brain disease? Neurology. 2002 Nov;59(10):1557-62. https://doi.org/10.1212/01.WNL.0000034256.20173.EA

12. Korfel A, Weller M, Martus P, Roth P, Klasen HA, Roeth A et al. Prognostic impact of meningeal dissemination in primary CNS lymphoma (PCNSL): experience from the G-PCNSL-SG1 trial. Ann Oncol. 2012 Sep;23(9):2374-80. https://doi.org/10.1093/annonc/mdr627

13. Rubenstein JL, Gupta NK, Mannis GN, Lamarre AK, Treseler P. How I treat CNS lymphomas. Blood. 2013 Oct;122(14):2318-30. https://doi.org/10.1182/blood-2013-06-453084

14. Wieduwilt MJ, Valles F, Issa S, Behler CM, Hwang J, McDermott $M$ et al. Immunochemotherapy with intensive consolidation for primary CNS lymphoma: a pilot study and prognostic assessment by diffusion-weighted MRI. Clin Cancer Res. 2012 Feb;18(4):1146-55. https://doi.org/10.1158/1078-0432.CCR-11-0625

15. Houang Xang K, Besell E, Bromberg J, Hottinger AF, Preusser $M$, Rudà R et al. Diagnosis and treatment of CNS lymphoma in inmunocompetent patients: guidelines from the European Association of Neuro-Oncology. Lancet Oncol. 2015;16(7):e322-32. https://doi.org/10.1016/S1470-2045(15)00076-5.

16. Oken MM, Creech RH, Tormey DC, Horton J, Davis TE, McFadden ET et al. Toxicity and response criteria of the Eastern Cooperative Oncology Group. Am J Clin Oncol. 1982 Dec;5(6):649-55. https://doi.org/10.1097/00000421-198212000-00014

17. Fine HA, Mayer RJ. Primary central nervous system lymphoma. Ann Intern Med. 1993 Dec;119(11):1093-104. https://doi. org/10.7326/0003-4819-119-11-199312010-00007

18. Bhagavathi S, Wilson JD. Primary central nervous system lymphoma. Arch Pathol Lab Med. 2008 Nov;132(11):1830-4

19. Preusser M, Woehrer A, Koperek O, Rottenfusser A, Dieckmann K, Gatterbauer B et al. Primary central nervous system lymphoma: a clinicopathological study of 75 cases. Pathology. 2010;42(6):547-52. https://doi.org/10.3109/00313025.2010.508786 
20. Swerdlow SH, Campo E, Pileri SA, Harris NL, Stein H, Siebert R et al. The 2016 revision of the World Health Organization classification of lymphoid neoplasms. Blood. 2016 May;127(20):2375-90. https://doi.org/10.1182/blood-2016-01-643569

21. Bataille B, Delwail V, Menet E, Vandermarcq P, Ingrand P, Wager $\mathrm{M}$ et al. Primary intracerebral malignant lymphoma: report of 248 cases. J Neurosurg. 2000 Feb;92(2):261-6. https://doi.org/10.3171/jns.2000.92.2.0261

22. Bühring $U$, Herrlinger $U$, Krings $T$, Thiex R, Weller $M$, Küker W. MRI features of primary central nervous system lymphomas at presentation. Neurology. 2001 Aug;57(3):393-6. https://doi.org/10.1212/WNL.57.3.393

23. Vaquero J, Martínez R, Rossi E, López R. Primary cerebral lymphoma: the "ghost tumor". Case report. J Neurosurg. 1984 Jan;60(1):174-6. https://doi.org/10.3171/jns.1984.60.1.0174

24. Hegde U, Filie A, Little RF, Janik JE, Grant N, Steinberg SM et al. High incidence of occult leptomeningeal disease detected by flow cytometry in newly diagnosed aggressive B-cell lymphomas at risk for central nervous system involvement: the role of flow cytometry versus cytology. Blood. 2005 Jan;105(2):496-502. https://doi.org/10.1182/blood-2004-05-1982

25. Weller M, Martus P, Roth P, Thiel E, Korfel A. Surgery for primary CNS lymphoma? Challenging a paradigm. Neuro-oncol. 2012 Dec;14(12):1481-4. https://doi.org/10.1093/neuonc/nos159

26. DeAngelis LM, Yahalom J, Heinemann MH, Cirrincione C, Thaler HT, Krol G. Primary CNS lymphoma: combined treatment with chemotherapy and radiotherapy. Neurology. 1990 Jan;40(1):80-6. https://doi.org/10.1212/WNL.40.1.80

27. Bellinzona M, Roser F, Ostertag H, Gaab RM, Saini M. Surgical removal of primary central nervous system lymphomas (PCNSL) presenting as space occupying lesions: a series of 33 cases. Eur J Surg Oncol. 2005 Feb;31(1):100-5. https://doi.org/10.1016/j.ejso.2004.10.002

28. Thiel E, Korfel A, Martus P, Kanz L, Griesinger F, Rauch M et al. High-dose methotrexate with or without whole brain radiotherapy for primary CNS lymphoma (G-PCNSL-SG-1): a phase 3, randomised, non-inferiority trial. Lancet Oncol. 2010 Nov;11(11):1036-47. https://doi.org/10.1016/S1470-2045(10)70229-1 